\title{
Hinf-I digestion of cytochrome oxidase / region is not a diagnostic test for A. m. lamarckii
}

\author{
Irfan Kandemir ${ }^{1,2}$, Maria A. Pinto ${ }^{3}$, Marina D. Meixner ${ }^{1}$ and Walter S. Sheppard ${ }^{1 *}$ \\ ${ }^{1}$ Department of Entomology, Washington State University, Pullman, WA, USA. \\ ${ }^{2}$ Department of Biology, Karaelmas University, Zonguldak, Turkey. \\ ${ }^{3}$ Centro de Investigação de Montanha, Campus de Santa Apolónia, Bragança, Portugal.
}

\begin{abstract}
Restriction fragment length polymorphism of whole mitochondrial DNA or PCR amplified mtDNA regions are known to be useful in discriminating among honey bee lineages and also some individual subspecies. In this study, PCR-amplified fragments of cytochrome oxidase I (CO-I) and cytochrome $B(C y t B)$ of honey bees sampled from different countries (Cyprus, Turkey, Ethiopia, Syria and Egypt) were digested with Hinf I and Bgl // restriction enzymes, respectively. Eastern Europe and Mediterranean honey bee subspecies were separated by the $\mathrm{Cyt} B / \mathrm{Bg} / \mathrm{Il}$ analysis, although Hinf I digestion of the CO-I region yielded much finer resolution within different honey bee lineages. Here we report that $\mathrm{CO}-\mathrm{I} / \mathrm{Hinf}-\mathrm{I}$ is a discriminative test for the mitochondrial "O" lineage, rather than a diagnostic site for $A$. m. lamarckii.
\end{abstract}

Key words: mtDNA, cytochrome oxidase I, Apis mellifera lamarckii, O lineage.

Received: November 1, 2005; Accepted: June 2, 2006.

Based on multivariate statistical analysis of morphometric characteristics, 26 honey bee subspecies have been recognized, divided into four evolutionary lineages (Ruttner, 1988; 1992; Sheppard et al., 1997; Sheppard and Meixner, 2003). For the most part, these evolutionary groupings have been supported by mtDNA and microsatellite analysis (Cornuet and Garnery, 1991; Garnery et al., 1992; Estoup et al., 1995). Most individual subspecies cannot be distinguished based on current mtDNA or nuclear DNA protocols. However, PCR amplification of the COI-COII intergenic region and digestion with Dra-I restriction enzyme has proven useful to differentiate among some honey bee subspecies. There are other diagnostic sites useful to differentiate evolutionary lineages, group of subspecies and a few individual subspecies (Sheppard et al., 1994; Palmer et al., 2000; Sheppard and Smith, 2000; Pinto et al., 2003). One of these subspecies, A. m. lamarckii, has been reported to be distinguishable by $C O-I$ region amplification and Hinf-I digestion (Nielsen et al., 2000). A. m. lamarckii was one of several African subspecies introduced into the United States prior to the arrival of Africanized honey bees (derived from A. m. scutellata). Here we investigated whether the phylogeographic distribution of this restriction

Send correspondence to Walter S. Sheppard. Department of Entomology, Washington State University, 252 FSHN Building, PO Box 646382, 99164-6382 Pullman, WA, USA. E-mail: shepp@mail. wsu.edu. fragment pattern is limited to $A$. $m$. lamarckii (Egypt) or whether it can be found in other subspecies including $A$. $m$. syriaca (Syria and Turkey), A. m. meda (Syria and Iran), $A$. m. cypria (Cyprus) and A. m. yemenitica (Ethiopia and Yemen).

Adult honey bee samples were collected from several countries, including Turkey (Kandemir et al., 2006), Northern Cyprus, Syria, Iran, Egypt and Ethiopia. Honey bees were stored either in $80 \%$ ethanol or frozen until laboratory analysis. Total nucleic acids were extracted following the methods of Sheppard and McPheron (1991) and Doyle and Doyle (1987). An approximately 1000 bp region of the cytochrome oxidase I (COI) gene and $800 \mathrm{bp}$ region of the cytochrome $B$ gene were amplified using primer pairs and PCR conditions previously reported (Sheppard et al., 1994; Nielsen et al., 2000; Crozier et al., 1991). After PCR, the amplified fragments for $C O I$ and $C y t B$ were digested with Hinf-I and Bgl II restriction enzymes, respectively, according to manufacturer's recommendations. Amplified PCR products were separated on a $1.5 \%$ agarose gel (Bio-Rad) and restriction enzyme digested fragments were separated on a $2.5 \%$ mixed agarose gel consisting of $1 \%$ agarose (Bio-Rad) and 1.5\% Nu-Sieve agarose (Nu-Sieve). Gels were stained with ethidium bromide, destained with distilled water and photographed under UV light.

With the exception of some samples from Ethiopia, all samples analyzed by $C y t B$ amplification and $B g l$ II di- 
Table 1 - Restriction analysis of PCR amplified CO I and $C y t B$ regions of mtDNA of honey bee samples collected from different countries.

\begin{tabular}{|c|c|c|c|c|c|c|c|}
\hline $\begin{array}{c}\text { COI/HinfI } \\
\text { Cut/Uncut } \pm\end{array}$ & $\begin{array}{c}\text { CytB/BglII } \\
\text { Cut/Uncut } \pm\end{array}$ & $\begin{array}{l}\text { Syria }(\mathrm{N}=35) \\
\text { A. m. syriaca, } \\
\text { A. m. meda }\end{array}$ & $\begin{array}{l}\text { Turkey }(\mathrm{N}=334) \\
\text { A. } \text { m. syriaca, } \\
\text { A. m. meda, } \\
\text { A. m. anatoliaca }\end{array}$ & $\begin{array}{c}\text { Cyprus }(\mathrm{N}=101) \\
\text { A. } \text { m. cypria }\end{array}$ & $\begin{array}{c}\text { Iran }(\mathrm{N}=174) \\
\text { A. m. meda }\end{array}$ & $\begin{array}{l}\text { Ethiopia }(\mathrm{N}=109) \\
\text { A. m. yemenitica, } \\
\text { A. m. scutellata, } \\
\text { A. m. monticola }\end{array}$ & $\begin{array}{l}\text { Egypt }(\mathrm{N}=62) \\
\text { A. m. lamarckii }\end{array}$ \\
\hline+ & + & 28 & 6 & 2 & 0 & 8 & 62 \\
\hline- & + & 7 & 328 & 99 & 174 & 83 & 0 \\
\hline - & - & 0 & 0 & 0 & 0 & 18 & 0 \\
\hline
\end{tabular}

gestion $(\mathrm{Cyt} \mathrm{B/Bgl} \mathrm{II)}$ exhibited a two-banded mitochondrial restriction fragment pattern (mitotype). This mitotype is generally considered to exclude $A$. $m$. scutellata as the possible subspecies of origin. However, when the cytochrome oxidase I (CO I) region of the same samples was digested with $\operatorname{HinfI}(\mathrm{CO} I / \operatorname{Hinf} I)$, further resolution of the middle eastern and east African honey bee population was achieved.

Out of 334 colonies from Turkey, 6 from the very southern end (within the geographic range of $A$. m. syriaca) showed the typical "A. m. lamarckii" CO I/Hinf I mitotype (Kandemir et al., 2006). Honey bee samples from northern Cyprus and Iran, A. m. cypria and A. m. meda, respectively, exhibited European mitotypes for both $C y t B / B g l I I$ and $C O$ I/Hinf I digestions, except two of the A. m. cypria colonies which had the $A$. m. lamarckii CO I/Hinf I mitotype. All samples from Egypt (A. m. lamarckii) showed the A.m. lamarckii CO I/Hinf I mitotype. Out of 35 samples from Syria (A. m. syriaca), 28 of them had the A. m. lamarckii CO I/Hinf I mitotype. Out of 109 Ethiopian samples, eight had A. m. lamarckii mitotypes (Table 1).

The analysis of the COI-COII intergenic region of honey bees from Syria and Turkey showed similar mtDNA restriction fragment patterns as has been found in $A . m$. lamarckii. Palmer et al. (2000) mentioned the presence of a fourth mtDNA lineage, but did not discuss the similarity to A. m. lamarckii. Similar findings were reported by Franck et al. (2000) based on COI-COII analysis of Lebanese honey bees. The results of their analysis of the COI-COII intergenic region indicated that honey bees from Lebanon (A. m. syriaca) had the same Dra-I restriction digestion pattern found in A. m. lamarckii. Due to the distinction of this pattern from African (A) restriction fragment patterns (other than those found in Egypt), they designated these new restriction fragment patterns as belonging to a mitochondrial lineage $\mathrm{O}$.

Our results show that the distribution of the COI/Hinf I mitotype "typical" of $A$. m. lamarckii is not restricted to Egypt, but is dispersed along the Nile river south toward Ethiopia and to the east to Yemen on the Arabian Peninsula. To the north, it extends to Turkey where the mitotype was found in the Hatay province that borders to Syria. Quite likely, this mitotype occurs in Israel, Palestine and Jordan as well. Although morphological data supports the placement of A. m. lamarckii within the African lineage, accu- mulated molecular data appears to contradict this grouping and suggests placement of $A$. m. lamarckii within a distinctive lineage (Arias and Sheppard, 1996; Franck et al., 2000). The use of $O$ as the designation for this distinctive mitochondrial lineage (Franck et al., 2000) may present confusion with the $\mathrm{O}$ morphological lineage described by Ruttner (1988). The distinctive morphological lineages C and $\mathrm{O}$ cannot be resolved easily using mitochondrial analysis and, thus, are both grouped within the C mtDNA lineage. Nonetheless, the " $A$. m. lamarckii" restriction fragment pattern (CO I/Hinf $I$ ) or "O" mitochondrial lineage (Franck et al., 2000) appears to be a widespread genetic variant. Further study of the distribution of this variant among the subspecies of the A and $\mathrm{C}$ morphological lineages will be important to fully understand the phylogeography of Apis mellifera.

\section{Acknowledgements}

This work was partially funded by TUBITAK-TBAG 2403, and BAYG-2219 scholarship to IK and by IFAFS Grant no. 2001-52103-11417 from the USDA-CSREES to WSS.

\section{References}

Arias MC and Sheppard WS (1996) Molecular phylogenetics of honey bee subspecies (Apis mellifera L.) inferred from mitochondrial DNA sequence. Mol Phylogenet Evol 5:557-566.

Cornuet JM and Garnery L (1991) Mitochondrial DNA variability in honeybees and its phylogenetic implications. Apidologie 22:627-642.

Crozier YC, Koulianos S and Crozier RH (1991) An improved test for africanized honeybee mitochondrial DNA. Experientia 47:968-969.

Doyle JJ and Doyle JL (1987) A rapid DNA isolation procedure for small quantities of fresh leaf tissue. Phytochem Bull 19:11-15.

Estoup A, Garnery L, Solignac M and Cornuet JM (1995) Microsatellite variation in honey bee (Apis mellifera L.) populations: Hierarchical genetic structure and test of the infinite allele and stepwise mutation models. Genetics 140:679-695.

Franck P, Garnery L, Solignac M and Cornuet JM (2000) Molecular confirmation of a fourth lineage in honeybees from the Near East. Apidologie 31:167-180.

Garnery L, Cornuet JM and Solignac M (1992) Evolutionary history of the honey bee Apis mellifera inferred from mitochondrial DNA analysis. Mol Ecol 1:145-154. 
Kandemir I, Kence M, Sheppard WS and Kence A (2006) Mitochondrial DNA variation in honey bee (Apis mellifera L.) populations from Turkey. J Apicult Res 45:33-38.

Nielsen DI, Ebert PR, Page Jr RE, Hunt GJ and Novoa-Guzman E (2000) Improved polymerase chain reaction-based mitochondrial genotype assay for the identification of the africanized honey bee (Hymenoptera, Apidae). Ann Entomol Soc Am 93:1-6.

Palmer MR, Smith DR and Kaftanoglu O (2000) Turkish honeybees: Genetic variation and evidence for a fourth lineage of Apis mellifera mtDNA. J Hered 91:42-46.

Pinto MA, Johnston JS, Rubink WL, Coulson RN, Patton JC and Sheppard WS (2003) Identification of Africanized honey bee (Hymenoptera, Apidae) mitochondrial DNA: Validation of a rapid PCR-based assay. Ann Entomol Soc Am 96:679-684.

Ruttner F (1988) Biogeography and Taxonomy of Honeybees. Springer-Verlag, Berlin, 284 pp.
Ruttner F (1992) Naturgeschichte der Honigbienen. Ehrenwirth, Munich, $357 \mathrm{pp}$.

Sheppard WS and McPheron BA (1991) Ribosomal RNA diversity in Apis. In: Smith DR (ed) Diversity in the Genus Apis. Westview Press, Boulder, pp 89-102.

Sheppard WS and Meixner MD (2003) Apis mellifera pomonella, a new honey bee subspecies from Central Asia. Apidologie 34:367-375.

Sheppard WS and Smith DR (2000) Identification of Africanderived bees in the Americas: A survey of methods. Ann Entomol Soc Am 93:159-176.

Sheppard WS, Arias MC and Shimanuki H (1994) Determination of mitochondrial DNA haplotypes from sting remnants of the honey bee Apis mellifera (Hymenoptera, Apidae). Bull Entomol Res 84:551-554.

Sheppard WS, Arias MC, Grech A and Meixner MD (1997) Apis mellifera ruttneri, a new honey bee subspecies from Malta. Apidologie 28:287-293.

Associate Editor: Klaus Hartfelder 